\title{
PENGARUH MEDIA POP UP BOOK TERHADAP NASIONALISME SISWA KELAS IV SEKOLAH DASAR
}

\author{
${ }^{1}$ Siti Agusyani Iskandar \\ ${ }^{2}$ Sinta Maria Dewi \\ ${ }^{3}$ Yulistina Nur DS \\ Program Studi Pendidikan Guru Sekolah Dasar \\ Fakultas Keguruan Dan Ilmu Pendidikan \\ Universitas Buana Perjuangan Karawang \\ Email sd17.sitiiskandar@mhs.ubpkarawang.ac.id
}

\begin{abstract}
ABSTRAK
Penelitian ini bertujuan untuk mengetahui pengaruh penggunaan media pop up book terhadap rasa nasionalisme siswa kelas IV sekolah dasar di SDN Palumbonsari III. Penelitian ini merupakan jenis penelitian kuantitatif. Populasi yang digunakan dalam penelitian ini seluruh siswa SDN Palumbonsari III. Dengan mengambil sampel 1 kelas sebanyak 20 siswa. Hasil dari uji validitas angket nasionalisme pada mata pelajaran IPS diperoleh 20 butir instrumen yang dinyatakan valid dari 35 butir instrumen yang diujicobakan. Hasil dari uji reabilitas diperoleh ri1 sebesar 0,906. Teknik pengumulan data melalui angket nasionalisme pada mata pelajaran IPS. Teknik analisis data untuk menguji hipotesis dilakukan dengan perhitungan statiska menggunakan uji-t. Hasil pengujian hipotesis, terdapat pengaruh yang signifikasi antara media pop up book pada nasionalisme siswa. Hal ini diperoh hasil rata-rata pretest sebesar 14,20 dan hasil posttest sebesar 15,35. Pada perhitungan T-test didapatkan nilai sig. (2-tailed) sebesar 0,000 yang artinya nilai 0,000 lebih kecil dari 0,05, menunjukan bahwa hipotesis Ha diterima. Berdasarkan penelitian ini maka dapat disimpulkan bahwa terdapat pengaruh media pop up book terdapat nasionalisme siswa.
\end{abstract}

\section{Kata kunci : Media Pop Up Book, Nasionalisme, IPS}

\section{ABSTRAC}

This study aims to determine the effect of using pop up book media on the sense of nationalism of fourth grade elementary school students at SDN Palumbonsari III. This research is a type of quantitative research. The population used in this study were all students of SDN Palumbonsari III. By taking a sample of 1 class as many as 20 students. The results of the test of the validity of the nationalism questionnaire on social studies subjects obtained 20 items which were declared valid from the 35 items tested. The results of the reliability test obtained rll of 0.906. Techniques for collecting data through nationalism questionnaires on social studies subjects. The data analysis technique to test the hypothesis is carried out by statistical calculations using the t-test. The results of hypothesis testing, there is a significant influence between pop up book media on student nationalism. This is obtained by the average pretest result of 14.20 and the posttest result of 15.35. In the T-test calculation, the sig value is obtained. (2-tailed) of 0.000, which means the value of 0.000 is smaller than 0.05, indicating that the hypothesis Ha is accepted. Based on this research, it can be concluded that there is an influence of pop up book media on student nationalism.

\section{Keyword: Pop Up Book Media, Nationalism, IPS}




\section{PENDAHULUAN}

Ilmu pengetahuan sosial (IPS) menjelaskan tentang bagaimana dalam kehidupan manusia melibatkan interaksi sosial antar masyarakat baik secara lokal maupun Internasional. Sosial sangat berperan penting bagi kehidupan manusia, karena untuk meningkatkan sosialisasi antar masyarakat dan lingkungan. Pada dasarnya IPS merupakan kajian tentang manusia dan dunia sekelilingnya. Hal ini berarti yang menjadi pokok kajian dari pelajaran IPS adalah hubungan antar manusia dan lingkungan di dalam kehidupan nyata manusia. Begitu pula IPS menjelaskan tentang sikap, keterampilan, pengetahuan, dan nilai pada siswa, agar dalam kehidupannya siswa mampu berinteraksi dengan lingkungannya.

Astawa (2017:42) menyatakan bahwa "IPS dirumuskan berlandaskan pada realitas dan fenomena sosial yang diwujudkan dengan pendekatan interdisipliner dari cabang-cabangIlmuil mu sosial. Tujuan pembelajaran IPS ialah mengembangkan potensi peserta didik agar peka terhadap masalah sosial yang terjadi di masyarakat, memiliki sikap mental positif terhadap perbaikan segala ketimpangan yang terjadi dan melatih keterampilan untuk mengatasi setiap masalah yang terjadi sehari-hari baik yang menimpa diri sendiri maupun masyarakat”.

Keterkaitan pembelajaran IPS dengan nasionalisme terhadap siswa sangat berperan penting untuk mengarahkan siswa dapat menjadi warga negara Indonesia yang demokratis, bertanggung jawab, serta warga dunia yang cinta damai, juga siswa dapat berinteraksi secara inividu atau kelompok. Menurut Gunawan (2011:37) menyatakn bahwa "Pembelajaran IPS bertujuan membentuk warga negara yang berkemampuan sosial dan yakin akan kehidupannya sendiri di tengah-tengah kekuatan fisik dan sosial, yang pada gilirannya akan menjadi warga negara yang baik dan bertanggung jawab".

Dalam pembelajaran IPS bermulanya pada pengukuran pemahaman siswa terhadap nasionalisme, yaitu siswa memperoleh rasa nasionalisme dalam afektif. Pada pemahaman pembelajaran IPS dalam materi keanekaragaman suku dan budaya siswa dapat menerapkan rasa nasionalisme di dalam dirinya. Nasionalisme merupakan sikap, rasa, dan tingkah laku untuk menunjukan rasa kecintaan tehadap negara dan tanah air, khususnya kepada suku dan budaya. Menurut Permanto (2012: 86) "Nasionalisme adalah suatu kesadaran bahwa tiap-tiap warga negara merupakan bagian dari suatu bangsa Indonesia yang berkewajiban mencintai dan membela negaranya, sehingga kewajiban seorang warga negara tersebutlah yang menjadi dasar bagi terbentuknya semangat kebangsaan Indonesia”.

Berdasarkan hasil observasi yang telah dilakukan terdapat permasalahan yang ada di SDN Palumbonsari III kelas IV pada mata pelajaran IPS ini dalam pembelajaran khususnya pada materi $\mathbf{5 0} \mid \mathrm{B}$ u a n a $\mathrm{I} 1 \mathrm{~m}$ u 
keanekaragaman suku dan budaya siswa belum mengenal akan adanya suku dan budaya, siswa kurang mengetahui dan hafal lagu kebangsaan dan lagu daerah, siswa kurang semangat pada saat belajar, siswa kurang mengetahui hari lahirnya para pahlawan Indonesia, serta siswa masih pasif saat pembelajaran. Jadi hal itu belum dapat meningkatkan rasa nasionalisme siswa terhadap negaranya sendiri.

Berdasarkan uraian di atas dapat disumpulkan bahwa untuk meningkatkan rasa nasionalisme siswa diperlukannya media pembelajaran. Menurut Asyar (2012:8) "Media pembelajaran dapat dipahami sebagai segala sesuatu yang dapat menyalurkan pesan dari sumber secara terencana, sehingga terjadi lingkungan belajar yang kondusif dimana penerimanya dapat melakukan proses belajar secara efisien dan efektif". Penggunaan media pembelajaran dapat dijadikan sebagai solusi untuk meningkatkan rasa nasionalisme siswa pada pembelajaran IPS di sekolah dasar, salah satu media pembelajaran yang dapat dan cocok untuk di terapkan pada siswa sekolah dasar salah satunya ialah media pop up book. Media pop up book menurut Dzuanda (2011:1) menyatakan bahwa "Media pop book adalah sebuah buku yang mempunyai bagian yang dapat bergerak atau memiliki unsur 3 dimensi serta memberikan visualisasi cerita yang lebih menarik, mulai dari tampilan gambar yang dapat bergerak ketika halamannya dibuka". Dimana media pop up book ini menitik beratkan pada gambar-gambar yang menarik yang dapat merangsang siswa dalam memahami materi pelajaran.

Dengan menggunakan media pop up book ini siswa lebih memperhatikan dalam pembelajaran IPS pada materi keanekaragaman suku dan budaya ssiwa akan lebih memeperhatikan dan dapat meningkatkan rasa nasionalisme terhadap dirinya, serta pada pembelajaran siswa menjadi aktif di dalam kelas.

\section{METODE PENELITIAN}

Penelitian ini menggunakan metode kuantitatif dengan jenis eksperimen. Desain penelitian menggunakan Quasi-experimental design dengan bentuk one-group pretest-posttest. Bentuk one-group pretest-posttest design seperti di bawah ini.

\section{Tabel 1}

Desain one-group pretest-posttest

\begin{tabular}{|c|c|c|}
\hline $\begin{array}{c}\text { Prestest } \\
\text { (pra treatment) }\end{array}$ & Treatment & $\begin{array}{c}\text { Posttest } \\
\text { (pasca treatment) }\end{array}$ \\
\hline $\mathrm{O} 1$ & $\mathrm{X}$ & $\mathrm{O} 2$ \\
\hline
\end{tabular}

Keterangan :

$\mathrm{O} 1=$ Nilai Prestest (sebelum diberi perlakukan)

$\mathrm{X}=$ Treatment

$\mathrm{O}_{2}=$ Nilai Posttest (sesudah diberi perlakuan) 


\section{Jenis Penelitian}

Instrumen merupakan titik tolak dari penyusunan variabel-variabel yang diterapkan untuk diteliti kemudian variabel-veriabel tersebut diberikan definisi opersional dan selanjutnya ditentukan indikator yang akan di ukur (Sugiyono, 2011:149). Instrumen yang digunakan dalam penelitian ini adalah koesioner berbentuk angket berupa pretest dan posttest.

\section{Waktu dan Tempat Penelitian}

Penelitian di laksanakan di SDN Palumbonsari III Kecamatan Karawang Timur, Kabupaten Karawang, Provinsi Jawa Barat. Waktu penelitian ini dilaksanakan pada bulan Januari-Agustus semester genap tahun ajaran 2020/2021.

\section{Target/Subjek Penelitian}

Populasi adalah wilayah generalisasi yang terdiri atas obyek atau subyek yang mempunyai kualitas dan karakteristik tertentu yang ditetapkan oleh peneliti untuk dipelajari dan kemudian ditarik kesimpulannya (Sugiyono, 2017:80). Adapun populasi dalam penelitian ini adalah seluruh siswa SDN Palumbonsari III yang berjumlah 20 siswa.

Sampel merupakan bagian dari jumlah dan karakteristik yang dimiliki oleh populasi (Sugiyono, 2013:18). Sampel penelitian ini diambil sebanyak 1 kelas dengan jumlah siswa sebanyak 20.

\section{Prosedur Penelitian}

Adapun rancangan yang akan dilakukan oleh peneliti pada saat penelitian, yaitu sebagai berikut:

\section{Tabel 1}

Rancangan Ekperimen

\begin{tabular}{|c|c|c|c|}
\hline No & $\begin{array}{c}\text { Langkah-Langkah } \\
\text { Kegiatan }\end{array}$ & Kegiatan Guru & Kegiatan Siswa \\
\hline 1 & Pendahuluan & $\begin{array}{l}\text { 1. Guru memasuki kelas dan } \\
\text { mengucapakan salam, } \\
\text { menanyakan kabar dan } \\
\text { mengecek kehadairan siswa. }\end{array}$ & $\begin{array}{l}\text { 1. Siswa menjawab } \\
\text { salam } \\
\text { 2. Siswa bersama-sama } \\
\text { membaca do'a }\end{array}$ \\
\hline
\end{tabular}


Siti Agusyani Iskandar, Sinta Maria Dewi, Yulistina Nur DS

Vol 6 No 1

ISSN : 2541-6995

E ISSN : 2580-5517

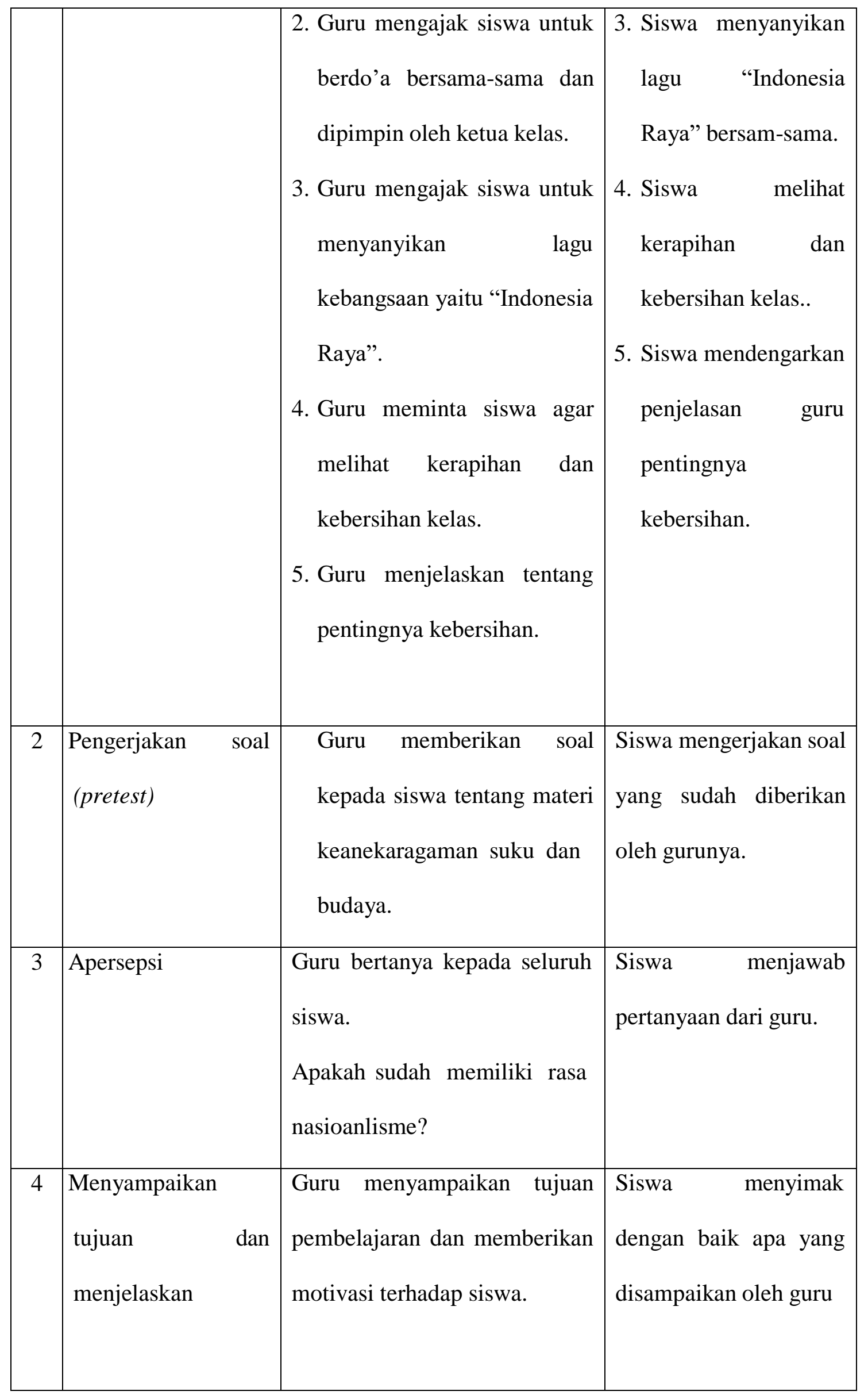


Siti Agusyani Iskandar, Sinta Maria Dewi, Yulistina Nur DS

\begin{tabular}{|c|c|c|c|}
\hline & $\begin{array}{l}\text { motivasi terhadap } \\
\text { siswa }\end{array}$ & & \\
\hline 5. & $\begin{array}{l}\text { Menjelaskan materi } \\
\text { pelajaran }\end{array}$ & $\begin{array}{l}\text { Guru menjelaskan dan } \\
\text { menyampaikan materi yang } \\
\text { akan di ajarkan kepada siswa } \\
\text { dengan menggunakan media } \\
\text { pop up book. }\end{array}$ & $\begin{array}{l}\text { Siswa mendengar dan } \\
\text { menyimak penejelasan } \\
\text { materi yang dijelaskan } \\
\text { oleh guru }\end{array}$ \\
\hline 6 & $\begin{array}{l}\text { Memberikan } \\
\text { kesempatan } \\
\text { bertanya }\end{array}$ & $\begin{array}{l}\text { Guru memberikan kesempatan } \\
\text { kepada siswa untuk } \\
\text { menanyakan materi yang } \\
\text { belum dipahami. }\end{array}$ & $\begin{array}{l}\text { Siswa bertanya } \\
\text { mengenai materi yang } \\
\text { belum dipahami. }\end{array}$ \\
\hline 7 & $\begin{array}{l}\text { Menjelskan media } \\
\text { pembelajaran pop } \\
\text { up book tentang } \\
\text { keanekaragaman } \\
\text { suku dan budaya }\end{array}$ & $\begin{array}{l}\text { 1.Guru menjelaskan materi } \\
\text { keanekaragaman suku dan } \\
\text { budaya dengan menggunakan } \\
\text { media pop up book } \\
\text { 2.Guru membagi kelompok dan } \\
\text { membagi tugas terhadap } \\
\text { masing-masing kelompok } \\
\text { untuk mengkaji materi } \\
\text { tentang keanekaragaman } \\
\text { suku dan budaya. Setiap } \\
\text { masing-masing kelompok } \\
\text { terdiri dari } 5 \text { orang siswa, } \\
\text { setiap kelompok yang maju } \\
\text { kedepan harus menyanyikan }\end{array}$ & $\begin{array}{l}\text { 1. Siswa mendengarkan } \\
\text { dan menyimak materi } \\
\text { keanekaragaman suku } \\
\text { dan budaya } \\
\text { 2.Masing-masing } \\
\text { kelompok lagu } \\
\text { menyanyikan atau } \\
\text { daerah } \\
\text { kebangsaan, dan } \\
\text { mengkaji materi } \\
\text { keanekaragaman suku } \\
\text { dan budaya sesuai sub } \\
\text { yang telah ditentukan } \\
\text { oleh gurunya. }\end{array}$ \\
\hline
\end{tabular}


Siti Agusyani Iskandar, Sinta Maria Dewi, Yulistina Nur DS

E ISSN : 2580-5517

\begin{tabular}{|c|c|c|c|}
\hline & & $\begin{array}{l}\text { terlebih dahulu lagu } \\
\text { kebangsaan atau lagu daerah } \\
\text { yang sudah disiapkan oleh } \\
\text { gurunya. }\end{array}$ & \\
\hline 8 & $\begin{array}{l}\text { Pengerjakan soal } \\
\text { (posttest) }\end{array}$ & $\begin{array}{l}\text { Guru memberikan soal kepada } \\
\text { siswa tentang materi } \\
\text { keanekaragaman suku dan } \\
\text { budaya. }\end{array}$ & $\begin{array}{l}\text { Siswa mengerjakan soal } \\
\text { yang sudah diberikan } \\
\text { oleh gurunya. }\end{array}$ \\
\hline 9 & Penutup & $\begin{array}{l}\text { 1. Guru mengambil hasil } \\
\text { posttest siswa. } \\
\text { 2.Guru memberikan kegiatan } \\
\text { tindak lanjut berupa tugas } \\
\text { rumah yaitu berdiskusi } \\
\text { dengan orang tua tentang } \\
\text { suku bangsa di lingkungan } \\
\text { tempat tinggal. } \\
\text { 3.Menyanyikan lagu Daerah } \\
\text { (Apuse) } \\
\text { 4. Ice breaking } \\
\text { 5.Kelas ditutup dengan doa } \\
\text { bersama. Salah satu siswa } \\
\text { memimpin doa untuk } \\
\text { mengakhiri pembelajaran. }\end{array}$ & $\begin{array}{l}\text { 1. Siswa } \\
\text { mengumpulkan } \\
\text { hasil posttest } \\
\text { 2. Siswa menyanyikan } \\
\text { salah satu lagu } \\
\text { daerah (Apuse) } \\
\text { 3. Ice breaking } \\
\text { 4. membaca do'a. }\end{array}$ \\
\hline
\end{tabular}




\section{Data, Instrumen, dan Teknik Pengumpulan Data}

Data penelitian ini diperoleh dari hasil angket nasionalisme yang sudah diisi oleh siswa kelas IV SDN Palumbonsari III. Data tersebut digunakan untuk mengetahui pengaruh media pop up book terhadap nasionalisme siswa kelas IV sekolah dasar.

Instrument penelitian yang digunakan untuk pengumpulan data dalam penelitian ini berupa koesioner berbentuk angket berupa pretest dan posttest

Teknik yang akan digunakan dalam penelitian ini yaitu teknik non tes berupa angket untuk mengetahui pengaruh media pop up book terhadap nasionalisme siswa kelas IV sekolah dasar.

\section{Teknik Analisis Data}

Teknis analisis data yang digunakan dalam penelitian ini yaitu:

\section{Statistik Deskriptif}

Ukuran statistik deskriptif dapat digolongkan menjadi dua kelompok, yaitu ukuran nilai tengah dan ukuran deviasi. Ukuran nilai tengah terdiri dari rata-rata mean, median, dan modus. Sedangkan ukuran deviasi terdiri dari varians, simpangan buku, koefisien variansi, dan nilai jarak (range).

\section{Statistik Inferensial}

a. Uji Normalitas

Dalam penelitian ini uji normalitas menggunakan uji Kolmogorov-Smirnov dengn bantuan SPSS 16.0 for windows dengan taraf $a=0,05$. Penggunaan uji Kolmogorov-Smirnov dengan menggunkan SPSS memiliki tingkat keakuratan yang lebih kuat jika banyaknya data atau sampel yang dianalisis kurang dari $50(\mathrm{n}<50)$. Uji normalitas ini dilakukan terhadap data pretest dan posttest (Ghozali, 2013:160) Alasan menggunakan uji Kolmogorov-Smirnov, yaitu karena uji ini digunakan untuk menguji data yang berskala interval dan ratio.

Adapun Kriteria pengujian hipotesis yang digunakan adalah sebgai berikut:

a) Jika nilai sig. $<0,05$ maka Ho ditolak

b) Jika nilai sig. $>0,05$ maka $\mathrm{Ha}_{\mathrm{a}}$ diterima 


\section{b. Uji Homogenitas}

Uji homogenitas dilakukan untuk mengetahui apakah siswa di kelas mempunyai variansi yang homogen atau tidak. Uji homogenitas dua varians terhadap hasil data pretest dan posttest menggunakan uji Levene dengan software Statistical Package For Sosial Sciences (SPSS) 16.0 for windows. Dengan kriteria menurut Sugiyono (2013 : 276) sebagai berikut :

Taraf signifikasi yang digunakan adalah $\alpha=0,05$. Uji homogenitas menggunakan SPSS dengan kriteria yang digunakan untuk mengambil kesimpulan apabila F hitung lebih besar dari $\mathrm{F}$ tabel maka memiliki varian yang homogeny. Akan tetapi apabila $\mathrm{F}$ hitung lebih besar dari $\mathrm{F}$ tabel, maka varian tidak homogen.

a) Jika nilai signifikansi $<0,05$ berarti data tersebut dinyatakan tidak homogen.

b) Jika nilai signifikansi > 0,05 berarti data tersebut dinyatakan homogen.

Dari hasil pengujian, data kedua kelompok memiliki varians yang sama maka dilakukan dengan kesamaan uji hipotesis dengan menggunakan uji one sample t test.

c. Uji t (test)

Uji t digunakan untuk menguji hipotesis dalam penelitian. t-test bertujuan untuk menguji perbedaan rata-rata nilai pretest dan posttest dari kedua kelompok. Menurut Arifin (2017:93) one sample t test atau uji t satu sampel merupakan teknik analisis untuk membandingkan satu variabel bebas. Teknik ini digunakan untuk menguji apakah nilai tertentu berbeda secara signifikan atau tidak dengan rata-rata sebuah sampel, atau untuk menguji perbedaan rata-rata suatu sampel dengan suatu nilai hipotesis. One sample t test menggunakan software Statistical Package For Sosial Sciences (SPSS) 16.0 for windows dengan taraf signifikan 0,05. Dengan kriteria sebagai berikut :

Jika $t$ hitung $>\mathrm{t}$ tabel maka Ho ditolak dan Ha diterima, jika $\mathrm{t}$ tabel $>\mathrm{t}$ hitung maka Ho diterima dan Ha ditolak. 


\section{HASIL PENELITIAN DAN PEMBAHASAN}

\section{Hasil Penelitian}

Pada penelitian ini yaitu siswa kelas IV SDN Palumbonsari III. Dalam kegiatan pembelajaran menggunakan media pop up book. Berdasarkan pengujian data analisis data, nilai rata-rata pretest yaitu 14,20 dan nilai rata-rata posttest sebesar 15,35.

Berikut disajikan uji analisis data statistik untuk menguji hasil data pretest dan posttest.

\section{Analisis Data}

\section{Uji Normalitas}

Pada uji normalitas untuk mengetahi sebaran data yang diperoleh dari hasil pretest dan posttest berdistribusi normal atau tidak. Dengan bantuan SPSS versi 16.0 dalam menghitung uji normalitas dihasilkan nilai sig (2-tailed) pada one sample Kolmogorov Smirnov yang dapat menunjukan normal atau tidaknya seberan data yang dihasilkan. Sebuah syarat data berdistribusi normal apabila signifikansi yang diperoleh dari hasil perhitungan lebih besar dari tingkat $\mathrm{a}=0,05$. Berdasarkan ujinormalitas pretest dan posttest dengan menggunakan uji Kolmogorov Smirnov diperoleh hasil sebagai berikut:

\section{Tabel 2}

\section{Hasil Uji Normalitas Pretest dan Posttest}

\begin{tabular}{|ll|r|r|}
\hline \multicolumn{2}{|c|}{ One-Sample Kolmogorov-Smirnov Test } \\
\hline $\mathrm{N}$ & Pretest & Posttest \\
\hline Normal Parameters ${ }^{\mathrm{a}}$ & Mean & 20 & 20 \\
& Std. Deviation & 14.20 & 15.35 \\
& Absolute & 2.067 & 2.159 \\
Most Extreme Differences & Positive & .239 & .214 \\
& Negative & .239 & .214 \\
& & -.181 & -.128 \\
& & 1.067 & .959 \\
Kolmogorov-Smirnov Z & & .205 & .317 \\
Asymp. Sig. (2-tailed) & & &
\end{tabular}

a. Test distribution is Normal.

Berdasarkan tabel di atas menunjukan bahwa nilai sig (2-tailed) pretest 0,205 posttest 0,317, hasil pretest dan posttest lebih besar dari 0,05. Maka sesuai dengan dasar pengambilan keputusan dalam uji normalitas Kolmogorov Smirnov di atas dapat disimpulkan bahwa data berdistribusi normal. Maka dari itu asumsi atau persyaratan normalitas sudah terpenuhi. 


\section{Uji Homogenitas}

Perhitungan uji homogenitas menggunakan SPSS Versi 16.0 for windows, dengan pedoman untuk mengambil kesimpulan adalah:

a) Jika nilai signifikansi $<0,05$ berarti data tersebut dinyatakan tidak homogen.

b) Jika nilai signifikansi $>0,05$ berarti data tersebut dinyatakan homogen.

\section{Tabel 4}

\section{Hasil Uji Homogenitas Pretest dan Posttest}

Test of Homogeneity of Variances

\begin{tabular}{|c|c|c|c|}
\hline Levene Statistic & df1 & $\mathrm{df} 2$ & Sig. \\
\hline .447 & & 38 & .508 \\
\hline
\end{tabular}

Diperoleh nilai signifikasi 0,508. Nilai yang dapat lebih besar dari 0,05. Dengan demikian, dapat disimpulkan bahwa variabel memiliki varian yang homogen.

\section{Uji-t}

Kriteria pengujian hipotesis (1) Jika nilai signifikasi atau sig.(2-tailed) > 0,05 maka Ho diterima dan ditoalk, (2) Jika nilai signifikasi atau sig. (2-tailed) $<0,05$ maka Ho ditolak dan Ha diterima.

Dari hasil uji-t diketahui bahwa nilai sig. (2-tailed) adalah 0,000 lebih kecil dari $a=$ 0,05, maka Ho ditolak. Dengan demikian Ha diterima yang berarti terdapat pengaruh media pop up book terhadap nasionalisme siswa.

\section{Pembahasan}

Pelaksanaan penelitian eksperimen ini melibatkan 1 kelas, yaitu kelas eksperimen. Kegiatan penelitian dilaksanakan pada bulan Juni 2021 di SDN Palumbonsari III tahun ajaran 2020/2021. Penelitian ini dilakukan kepada siswa kelas IV SDN Palumbonsari III, untuk meningkatkan rasa nasionalisme siswa pada mata pelajaran IPS materi keanekaragaman suku dan budaya. Penelitian tersebut dilakukan dengan mengunakan media pop up book, dengan jumlah sampel 20 siswa.

Setelah dilakukan penelitian, maka didapatkan hasil pretest dan posttest, hasil posttest siswa yang telah diberikan treatment dengan menggunakan media pop up book lebih tinggi dari pada siswa yang tidak diberikan treatment. Berdasarkan hasil data yang diperoleh menunjukan 
bahwa hasil pretest dan posttest berbeda, dengan nilai rata-rata pada posttest 15,35 lebih tinggi dibandingkan dengan nilai rata-rata pada pretest 14,20.

Hasil uji-t menunjukan bahwa ada pengaruh penggunaan media pop up book terhadap nasionalisme siswa kelas IV. Hal ini sesuai denga perhitungan program SPSS 16.0 for windows yang menggunkan analisis uji-t yang menggunkan taraf signifikasi 0,05. Hasil perhitungan data menunjukan bahwa nilai signifikasi $(0,000<0,05)$. Dengan demikian Ha diterima dan Ho ditolak. Hal ini membuktikan bahwa terdapat pengaruh penggunaan media pop up book terhadap nasionalisme siswa kelas IV. Penelitian ini dilakukan sesuai denagn prosedur pelaksanaan mulai dari perencanaan dan pelaksanaan penelitian.

Dengan demikian peningkatan terhadap rasa nasionalisme siswa yang diberikan teratment lebih baik dari pada yang tidak diberikan treatmnet. Jadi rasa nasionalisme siswa meningkat sesuai dengan indikator cinta tanah air, menjaga kesatuan dan persatuan, rela berkorban demi bangsa dan negara, menghargai jasa-jasa pahlawan, dan melestarikan budaya khas Indonesia.

\section{KESIMPULAN DAN IMPLIKASI}

\section{Kesimpulan}

Berdasarkan hasil penelitian dan analisis data, maka dapat disimpulkan bahwa penggunaan media pop up book berpengaruh terhadap nasionalisme siswa kelas IV sekolah dasar di SD Negeri Palumbonsari III. Berdasarkan hasil penelitian dan analisis data rata-rata pretest 14,20, setelah diberikan treatment dan melakukan posttest bahwa hasil akhir 15,35. Perhitungan hipotesis dilakukan menggunkan uji-t yakni uji one sample t test dan di peroleh taraf signifikasi 0,05 menunjukan bahwa nilai sig. (2-tailed) adalah 0,000, karena nilai signifikasi, maka Ho ditolak. Hal ini membuktikan bahwa penggunaan media pop up book berpengaruh terhadap nasionalisme siswa kelas IV sekolah dasar SD Negeri Palumbonsari III.

\section{Implikasi}

Bagi peneliti yang ingin meneliti media pop up book, peneliti ini dapat dijadikan sebagai acuan atau referensi untuk membantu dalam melakukan penelitian. Selain itu karena peneliti ini baru mengungkapkan media pop up book dengan nasionalisme siswa, diharapkan peneliti lain dapat melanjutkan penelitian ini dengan membahas media pop up book dikaitkan dengan faktor lain. 


\section{DAFTAR PUSTAKA}

Astawa, Ida Bagus Made. 2017. Pengantar Ilmu Sosial. Depok: Rajagrafindo.

Dzuanda, B. 2011. Perancangan Buku Cerita Anak Pop up Tokoh-tokoh Wayang Berseri, Seri Gatotkaca. http://digilib.its.ac.id/index.php. Diakses pada 25 Januari 2021.

Ghozali, Imam. 2013. Aplikasi Analisis Multivariat dengan Program IBM SPSS. Edisi 7. Semarang: Penerbit Universitas Diponegoro.

Gunawan, Rudi. 2011. Pendidikan IPS-Filososi, Konsep dan Aplikasi. Bandung. Alfabeta.

Rayanda, Asyhar. 2012. Kreatif Mengembangkan Media Pembelajaran. Jakarta: Gaung Persada (GP) Press Jakarta.

Sugiyono. 2011. Metode Penelitian Kuantitatif, Kualitatif dan R\&D. Bandung:

Afabeta.

Sugiyono. 2013. Metode Penelitian Kuantitatif, Kualitatif dan R\&D. Bandung: Afabeta

Permanto, Toto. 2012. Perilaku Nasionalistik Masa Kini dan Ketahanan Nasional: Penerapan Perilaku Nasionalistik Masa Kini. Hlm. 86-88. Yogyakarta: Mata Bangsa 